\title{
Ethel Carnie Holdsworth: genre, serial fiction, and popular reading patterns
}

Book or Report Section

Accepted Version

Wilson, N. (2017) Ethel Carnie Holdsworth: genre, serial fiction, and popular reading patterns. In: Goodridge, J. and Keegan, B. (eds.) A History of British Working Class Literature. Cambridge University Press, Cambridge. ISBN 9781107190405 doi:

https://doi.org/10.1017/9781108105392.021 Available at http://centaur.reading.ac.uk/66084/

It is advisable to refer to the publisher's version if you intend to cite from the work. See Guidance on citing.

To link to this article DOI: http://dx.doi.org/10.1017/9781108105392.021

Publisher: Cambridge University Press

All outputs in CentAUR are protected by Intellectual Property Rights law, including copyright law. Copyright and IPR is retained by the creators or other copyright holders. Terms and conditions for use of this material are defined in the End User Agreement. 


\section{www.reading.ac.uk/centaur}

\section{CentAUR}

Central Archive at the University of Reading

Reading's research outputs online 
Dr Nicola Wilson

Author final version

This is the version accepted by the publisher; it includes corrections after peer

review but it has not yet been copyedited or typeset by the publisher. (Green

Open Access). 
Ethel Carnie Holdsworth: Genre, Serial Fiction, and Popular Reading Patterns Nicola Wilson

In November 1913, the monthly journal of the Co-operative Society, The Wheatsheaf, introduced Lancashire mill woman Ethel Carnie Holdsworth (then Miss Ethel Carnie) and her first novel published in book form to its readers. Partly biographical portrait and partly review, the article was prefaced by a critique of working-class women's reading habits. The opening sketch, based upon a private conservation between two women in a railway carriage, makes interesting reading on many levels:

In a Lancashire railway train not long ago two typical wives and mothers of the better-paid working class were talking of another woman who read books. One of the matrons declared that she herself had not done ten minutes' reading in the past year. Her companion replied, confessing that she, too, had not read a book for years. "There's too much to do in a house, wi' so many of 'em." (“"Miss Nobody' - and its Author" 85)

Whether this account is fictive or grounded in reality, the eavesdropper's attitude towards the women is fairly clear. The loaded commentary continues in the following manner: 
Although it would be as hard upon oneself not to go outdoors for ten minutes in a year, or never to ride in any railway carriage or other vehicle for years, this attitude towards books and papers is still shared by great numbers of married women. Owing to the pressure of housework, not to read becomes a habit, and by-and-by the habit is half boasted as a virtue. It is not always because the housework itself is so heavy, but because there is ever some homely duty, perhaps a trifling duty, which nevertheless will claim precedence if it is allowed. (85)

The reviewer's dismissal of women's talk and working-class culture here reverberates throughout my discussion in the rest of this chapter. The invocation of a supposedly typical incident and the appeal to recognizable character types is surely meant to encourage the readers of The Wheatsheaf to dis-identify with the gossiping matrons. The tone, though perhaps not meant to be offensive, is dismissive of "trifling" domestic duties and harsh towards what is presented as the deliberately obtuse: "no reading means less thinking outside the little homely round of life and less expression of thoughts" (85). Whether or not the reader would have seen themselves reflected in the attitudes of the women in the railway carriage or sided more readily with the opinions of the reviewer, the scene is introduced to juxtapose the subsequent portrait of Carnie Holdsworth, "herself a working woman" it is noted, "a writer possessing an instinctive sympathy with her sisters" who might, by dint 
of her apparent rarity in literary and publishing circles, begin to "exert $[\ldots]$ a due influence upon the opinions and life of the world" (85).

The disinclination towards reading apparent in The Wheatsheaf's female railway characters is a typical feature in conceptualizations of workingclass women's history and social attitudes. In her study of Middlesbrough, At the Works, published in 1907 for instance, social explorer Lady Florence Bell found that "the workman reads, as a rule, more than his wife" precisely because of such difficulties for women in finding "more definitive times of leisure" and the long association of reading and "sitting down with a book" with guilt and unjustified rest (145). But there is another side to this picture. As contemporary historians of gender and leisure suggest, there was a complex, ambiguous relationship for working-class women with activities categorized as "leisure" as well as between "work" and "home" (Langhamer 2). Reading - Carnie Holdsworth knew well - was not necessarily a solitary nor a domestic pursuit. There were different types of informal reading experiences and publishing venues that sidestepped the kind of private, unhurried time involved in "sitting down with a book." In an early article for Robert Blatchford's newspaper The Woman Worker for instance, Carnie Holdsworth takes evident delight in exposing the stolen culture of reading in the mills:

If you took a stroll through a cotton mill whilst the "hands" were away in their homes having dinner, and were inquisitive enough to poke into 
the square, tin boxes that are for the purpose of holding weft, you would find a varied assortment of literature. You might find, deftly hidden (lest the eagle eye of the overlooker pop on them), Conan Doyle, Rider Haggard, Silas Hocking, Dickens, "Daily Mail," "Comic Cuts," and (sometimes) the "Clarion" ("Factory Intelligence" March $10,1909,219)$.

"Perhaps you will say that factory workers ought not to read in their masters' time?" she continues before answering: "Why should factory toilers spend more than half their lives in the service of others and never have time to live?"

Throughout her writing career, Carnie Holdsworth adopted a number of different forms - poetry, short stories, journalism, serial fiction, children's stories, and book-length novels - in order to reach a wide reading audience and to address those men and women unable to spend long periods of time sitting down reading at home. As a working-class woman and socialistfeminist committed to the Labour movement in its many guises, Carnie Holdsworth adopted an eclectic and pragmatic approach to writing that made the most of different publishing formats and capitalized upon the great expansion in reading and print culture in the early decades of the twentieth century. The full extent of Carnie Holdsworth's literary and journalistic output is still unknown. With no diaries, only a handful of letters, and few records of her writing life preserved - as is often the case with writers from a workingclass background - the rare surviving copies of her novels that were published 
in book-form are important literary evidence. Ongoing research into her voluminous shorter pieces and sketches for periodicals - national, provincial and foreign - has so far only scratched the surface of what was clearly an important market for her work. By 1932 at least, the "Ex-Mill Girl Who Became a Literary Celebrity" had, according to The Yorkshire Observer, written a total of "ten novels, 15 serials, two films, and a host of short stories, essays and poems" (April 5, 1932, 11). This chapter explores three key dimensions to Carnie Holdsworth's work and literary oeuvre: the attitudes to literature and popular reading patterns in her work; her writing as a newspaper and serial novelist; and how these things combined to produce a purposively eclectic and radical approach to form and genre.

Born into a Lancashire weaving family in 1886, Carnie Holdsworth was immersed in a rich autodidact and literary culture. Her published work shows she was extremely well read and her knowledge of literature was extensive. As a child and half-timer, she borrowed books from Great Harwood's Co-operative Lending Library and as a teenager was supported by the Blackburn Authors' Society. Her first published poem, "A Bookworm," with its rapturous depiction of "The world of books," is a testament to the imaginative possibilities of creative writing and the power of the printed word to enact change. This is something Carnie Holdsworth would champion throughout her career and work towards through various means: by journalism 
and creative writing, education and teaching, and a passionate advocacy of public lending libraries and the work of the Co-operative Education Movement. In July 1923, with a radical penny monthly at her disposal (she ran The Clear Light with her husband from their home near Hebden Bridge between 1923 and 192-5), Carnie Holdsworth sought donations from her readers for a scheme to distribute books freely amongst the people, starting with the agricultural workers in Norfolk who were on strike (Smalley 105). As a former factory worker, she was equally concerned with the human labor involved in the book making, printing, binding, and paper trades. In her first published novel, Miss Nobody (1913), the protagonist works briefly in a Christmas-card factory, where the "grinding" of the printing press "seemed to shake the hot, gaslit room" and the girls folding paper insets are exploited and run down (139). In the summer of 1914, she announced her support for the Esher bookbinders' strike in a poem "Book-makers and Bookbinders," which was printed in the Daily Herald (June 16, 1914).

In many of Carnie Holdsworth's novels and short stories, reading and print culture help to define the protagonists' sense of self and to offer powerful leitmotifs of change and possibility. The reading matter enjoyed by her characters is eclectic. While Carrie Brown, the heroine of Miss Nobody, reads yellow-backed novelettes, Rachel Martin, the political agitator of industrial novel This Slavery (1925) ploughs through Marx and Edward Clodd's popularizations of evolutionary theory. William Morris's socialist utopia News from Nowhere, or an Epoch of Rest: Being Some Chapters from a Utopian 
Romance (1890) underpins This Slavery's scenes of domestic harmony and filial love. In General Belinda (1924), the eponymous heroine has "followed the poets ever from being a child, and her father has 'poeted' in his lifetime $[\ldots]$ but never got nothing published" $(121,97)$. Over the course of this novel and its heroine's "long Odyssey of domestic service" (back cover blurb), we are told that Belinda "knew and loved Omar Khayyam" (28) and has read H. G. Wells, Charles Lamb, Shakespeare, and John Ruskin. At one point, she owns only “a change of clothes, Napoleon's Book of Fate and Hugo's First French Course, and a little copy of Silas Marner which she had found wet with rain in the street when she was on an errand" (102). While in the employ of a "literary man" who lectures on Robert Burns and William Blake, Belinda “dip[s] into Plato's Republic, [and] wept over Les Miserables," which she reads from a "badly-printed page" (125). As Roger Smalley has pointed out, "[t]he writers Ethel valued for their fictional support of her political vision" (105) are most obvious in the many intertextual references in this book.

Though throughout her working life Carnie Holdsworth would campaign to improve working-class education and for greater material access to literary and print culture, she had none of the scorn for working-class reading habits typical of many social commentators. Imaginative freedom, creative and aesthetic pleasure - what she called, in early material for The Woman Worker, "colour" - could as she well knew take a variety of forms ("How Colour is Introduced" April 7, 1909, 323). As Pamela Fox has pointed out, Carnie Holdsworth was well aware of the pleasures of popular mass 
entertainment like the new "cinematograph" and its power to transport viewers away from home and mill ("Introduction" Helen of Four Gates, xiv). It was this recognition of the necessity for human pleasure and imaginative escape "We are not tin men and women: we have blood in our veins and eyes in our head, and want some sunshine and blue sky and bird-songs" - that characterized Carnie Holdsworth's lifelong disdain for the categories of high and low culture ("How Colour is Introduced" April 7, 1909, 323). As she points out in an early article about reading and "Factory Intelligence," it needed perseverance and patience, not to mention perspicacity, to attempt reading in the busy working conditions of a mill: "In some six hours, with good luck, you may manage two pages of pretty open print" ("Factory Intelligence" 219). Read furtively "between the breaking of the threads and the throwing of the shuttle" ("Factory Intelligence" 219), adventure stories, thrillers, melodrama, and romance were popular, entertaining genres to sustain interest and memorability.

Growing up as a factory girl, Carnie Holdsworth was well aware that literary taste and the form that print is bound up in - in addition to the means used to acquire it - were intimately related to class. In General Belinda, an interesting exchange on the politics of reading takes place when Belinda inadvertently burns the patties for a particularly tyrannical employer (she has been sent out on an affaire de coeur for her employer's daughter, Cora): 
"Do you mean to say you have allowed the patties to burn, Higgins?" almost shrieked Mrs. Riddings. “Good gracious! I can’t take a needed rest but everything goes wrong. I suppose you were reading some trashy romance." (75)

Belinda is rightly annoyed by the intrusive and judgmental disparagement of her reading habits: “'If I like a bit o' luv,' she said, indignantly, 'I don’t see that it matters to you"' (75). Mrs. Riddings, we are told, "herself read every novel, in its expensive edition" (75), meaning that she belonged to a feepaying circulating library where newly published ("expensive") editions were stocked. Though Mrs. Riddings is snobbish about cheaper, "trashy" romances produced for working-class budgets, the "expensive editions" of novels in circulating libraries were just as likely to be "trashy" in tone. ${ }^{\text {ii }}$

The pleasures and values involved in the reading of "trashy romance" are also explored in Miss Nobody. This was first serialized in The Christian Commonwealth (The Organ of the Progressive Movement in Religion and Social Ethics) between June and September 1913, prior to being published in book form by Methuen in their "Popular Novels" series in autumn 1913. Miss Nobody is the story of the resourceful Carrie Brown, "an oyster-girl from the city" (61) who decides to sell up and leave Manchester when she receives an offer of marriage from a country farmer, Robert Gibson. Carrie is schooled in the popular romances of cheap yellowbacks: novels bound with glazed colored papers over strawboards and boasting attractive pictorial covers, often 
associated with railway reading and sold at one or two pence. On her train journey out to visit her sister in Greenmeads, we first meet Carrie transported by "colour":

[S]he drew from her coat-pocket a yellow-backed "Tulip Novelette" entitled “The Duchess of Digglemore's Diamonds." It was written by a poor pot-boiler who had once cherished dreams of rising to the heights of the immortal ones, joining the choir invisible, but who had found the road too hard, and writing for posterity a thankless task.

When he received the cheque for that impossible story he had broken his fast with a mutton chop, sighing a little, too, and telling the children not to make so much noise, as the flat wasn't all theirs.

Carrie thought that the author must have been a personal friend of the Duchess to know the exact shade of her eyes. Perhaps he had been a former lover, and had sat in that exquisite room to be able to describe it so minutely.

Instead of the gritty floor of the oyster-shop she [Carrie] trod soft Persian carpets upon which lovers knelt to propose in long-winded poetical sentences as sweet as barley-sugar, and not half as wholesome $[\ldots]$

Carrie herself was the Duchess for the time being. (9-10) 
Like Austen's Northanger Abbey (1817), Miss Nobody highlights the gap between popular fiction and economic and social reality - part of Carrie's own Bildungsroman is to adapt to the "mixed up" realities of love and marriage (60). There is clearly a distinction set up for the reader here between the knowing voice of the narrator - aware of the economic reality of authorship, for instance - and Carrie's imaginative naiveté, supposing, as she does, that the author must be a friend or lover of the imaginary Duchess. But even if this gap in knowledge is set up for the reader, we are not invited to sneer. What wins out in the description of Carrie's imaginative freedom here are the visceral pleasures to be gained from reading "yellow rubbish," as Carrie's scornful elder sister-in-law calls it (77).

II

Following a visit from Robert Blatchford to her home in Great Harwood in July 1908 and an invitation to join the staff on his London-based newspaper, The Woman Worker, Carnie Holdsworth left the mills (she would go back for a time during 1910-11) and developed connections with a number of periodicals. In addition to writing short stories, articles and poems for The Woman Worker (which she also edited between July and December 1909), she wrote for other newspapers and magazines including Woman's World, The Red Letter, Horner's Weekly, English Illustrated Magazine, Woman, Cooperative News, The Millgate Monthly, The Clarion and the two Blackburn weeklies, The Weekly Telegraph and Blackburn Times (Frow 258). She also 
contributed a variety of work - travel articles, sketches, poems, and serial fiction - for the Co-operative movement's free publication The Wheatsheaf, as well as The Christian Commonwealth, and The Sunday Worker. The expansion of the popular press in the late nineteenth century and the development of mass-market penny papers and magazines aimed at working class readers (the most successful, George Newnes's Tit-Bits, was selling more than 600,000 copies a week by 1893) created an important new reading market for an aspiring writer from a working-class background (Nash 9). While for many social commentators, the "New Journalism" (so called by Matthew Arnold) was a source of some anxiety (Nash 9), for a politically-committed workingclass writer like Carnie Holdsworth the great expansion in the newspaper and magazine market meant increased opportunities both to publish and to reach a mass reading audience.

Carnie Holdsworth's remuneration for her piecework in periodicals is difficult to quantify. As Walter Besant, head of the Society of Authors, advised in The Pen and The Book (1899) - a well-known manual aimed at "those who are thinking of the Literary Life" (v) - there was no fixed rate of pay for writers with many journals. "[A] guinea a page," wrote Besant, "the page varying from 500 to 1,000 words, is a common sum to offer. [...] For a short story of two of three columns in a weekly, the author may expect as many guineas and sometimes will have to take less" (229). In terms of what we know of Carnie Holdsworth's career overall, her efforts to live by her pen were clearly precarious. When she lost her regular salary at The Woman 
Worker at the end of 1909, for instance, she "took the line of least resistance and went back into the factory again" ("Ex-Mill Girl” 11). She completed Miss Nobody slowly while "working on 'bread-and-butter' work" including short story work for magazines and newspapers in addition to shop work with her mother in Ancoats ("The Authoress of Our New Serial Story" The Cooperative News, July 21, 1915, 999; Smalley 49). Just over a decade later, even after the bestselling success of Helen of Four Gates (1917) which enabled her to buy a former inn between Todmorden and Hebden Bridge and offered a brief period of financial stability (Smalley 70), Carnie Holdsworth could write that: "as one who was half-starving in the richest city in the world only three years ago, with husband and two kids, I can see nothing in dry crusts but - dry crusts" (Sunday Worker July 26, 1925, 6).

One of the most profitable areas for the aspiring writer of the early twentieth century to exploit was the rapidly growing market for serial fiction. This was both an important income stream and a popular source of workingclass reading material and entertainment. The average serialized story appearing in a weekly newspaper format closely approximated the "two pages of pretty open print" that Carnie Holdsworth had estimated was possible to read during "some six hours, with good luck" at the mill ("Factory Intelligence" 219). It is much more likely that the "factory toilers," who Carnie Holdsworth first worked among, would have read her novels in weekly serial format than in their later iterations in hard-back. ${ }^{\mathrm{iii}}$ Many of the novels were first published as serials. This includes Miss Nobody, General Belinda, 
The Marriage of Elizabeth (1920), The House that Jill Built (1920), and This Slavery, while other serial fictions that were not later published in book form are still being discovered. ${ }^{\text {iv }}$ Weekly newspapers like The Christian Commonwealth and The Co-operative News which contained two of Carnie Holdsworth's earliest serial fictions - "Miss Nobody: A Working Girl's Love Story” (June-September 1913) and “The Iron Horses” (July-December 1915) respectively - were sold at one penny and could easily be passed around, circulated, and shared. The advertisement of serial fiction - long-regarded as an intimate, interactive form of communication - was widely used by newspaper publishers and socialist periodicals to attract working-class readers and create a sense of community (Mutch xxiii). In a postcard addressed to “(Mrs or Miss) W. Hardisty” on September 10, 1924, thanking her for her appreciation of "This Slavery," Carnie Holdsworth wrote “"This Slavery' is not yet out in book form - truth to tell I have not had time to paste out all the serial cuttings completely yet." (E. Holdsworth to W. Hardisty, September 10, 1924. Hebden Bridge Local History Society archive, MISC $8 / 4)^{\mathrm{v}}$ But she included a free copy of The Clear Light, the one-penny monthly of the National Union for Combating Fascism that she published with her husband Alfred. This, she pointed out, included "another serial of mine, which some readers have thought better than 'This Slavery."' (as above: E. Holdsworth to W. Hardisty, September 10, 1924. Hebden Bridge Local History Society archive, MISC 8/4) 
There only were meager profits for the writer of the average first novel published in hard-back. As the authors of How to Write Serial Fiction pointed out, the novel was likely to "yield[] a gross return of about $£ 40[\ldots]$ barely enough to cover the author's typing expenses." (Joseph and Cumberland 9). The demand for serial fiction on the other hand was great, the market potentially easier to penetrate, and the "payment is good compared to other forms of work" (16). Average payment for a serial was similar to that of a short story - namely two to three guineas per thousand words. But with the average serial story in a newspaper running to 60,000 words, this could add up, Joseph and Cumberland calculated, to $£ 240$ a story: "So, it will be seen that a young writer who can manage to sell only two serials a year can provide himself with a respectable income" (30). In addition to first British serial rights, there were other saleable rights involved, including book rights, "the second British serial rights, foreign serials rights, colonial serial rights, and film rights" (31). Carnie Holdsworth experimented with the latter and was successful in selling the rights to Helen of Four Gates in addition, apparently, to The Taming of Nan (though there is no evidence that a film was ever made of the latter) (Smalley 72, 75 n47). Despite her enthusiasm for the "Living Pictures," however, she was clearly not as successful in exploiting the new world of the cinematograph as some of her more popular female contemporaries like Elinor Glyn or Ethel M. Dell (The Woman Worker 416). The radical political content of Carnie Holdsworth's writing is one obvious reason for this. The scenes of domestic violence in the film version of Helen of 
Four Gates (Director Cecil Hepworth, Hepworth Picture Plays, 1921) for instance, raised concerns that viewers would be off put (Smalley 72). We do not know how Carnie Holdsworth placed her earliest serial fictions, "Miss Nobody: A Working Girl's Love Story" and "The Iron Horses" with national periodicals. Possibly, this was through personal contacts she made during her early years as a journalist and freelance writer living in London. But there is evidence from one of her rare surviving letters that after she signed a contract with the publisher, Herbert Jenkins, in May 1915 for Helen O' Four Gates (in addition to her next six novels), there was some initial confusion about the placing of serial rights. In July 1917, she wrote in clarification to the Authors' Syndicate Ltd, which had been set up by William Morris Colles around 1890 to handle the business of members of the Society of Authors, that "Mr Jenkins [...] is quite agreeable for me to have my novels - prior to publication as books - serialised. Do you think you could approach some of the better kind of magazines re my next novel being serialised?"vi Following evident disappointment with a newspaper serial that had been started but not completed, she wrote in this letter that she planned to prioritize the novels over short story work for the time being. During World War One she worked on several novels in addition to campaigning for the British Citizen Party (see Smalley 63-7). Three of these were published by Herbert Jenkins in 1920.

But Carnie Holdsworth remained a "newspaper novelist" (Law xi) and clearly continued - presumably with the aid of a different newspaper syndicate 
or literary agent after the Authors' Syndicate folded in 1926 - to sell the foreign and colonial serial rights to her work. The latest serial story that we know of to date, "The Beggar Prince," discovered by historian Chris Lynch in a recently digitized version, appeared in The Age (Melbourne, Victoria) over a period of five weeks daily from the end of November to the end of December, 1932. In one earlier twelve part serial, "The Great Experiment," published weekly in The Queenslander (Brisbane) between December 1922 and March 1923, working-class authorship is a key theme. Cora Drummond, "beautiful author of the underworld" (“A Great Experiment” The Queenslander, January $6,1923,42)$ turns to writing to counter her husband's "slumming" and the noxious attitudes of the upper-class family she marries in to. In some ways the story is Carnie Holdsworth's repost to George Bernard Shaw's Pygmalion (1913). Taken out of her native home, Cora wants to write about the lives of her family and friends in Fiddle-Row and is encouraged to publish by a sympathetic Professor who advises her to study Flaubert's short story form for construction and literary technique (February 24, 1923, 42). At the end of the story, again perhaps in a rebuttal to the conclusion of Shaw's famous play, Cora's writing serves to unite estranged husband and wife as they decide to "work together," with Cora's "little sketches of live people" guaranteeing the success of her husband Henry's plays (March 17, 1923, 42). 
In critical assessments, Carnie Holdsworth has long been regarded as a writer difficult to pin down. While her poetry and early fiction was compared to the work of Longfellow, the Brontë sisters, and Thomas Hardy, for others there was a confusion of genre in her writing, particularly revolving around her use of melodrama and romance. In a review of This Slavery for The Plebs for instance, we find that "[This Slavery] strikes the real, proletarian note; and this makes one regret all the more certain melodramatic passages and incidents which really detract from its strength. 'Penny plain' is always more effective than 'twopence coloured"” (H.O.B. "A Propaganda Novel" The Plebs. October 1925, XVII, 408-9). Questions about the comparative value of different style, genre, and reading patterns continue to affect interpretation of her work. As David Malcolm points out in a review of the centenary re-publication of Miss Nobody: "Like much of Carnie's fiction, Miss Nobody is a complex mixture of social realism and melodrama, of the kind of popular women's romance that Carrie herself reads, and gritty observation of poverty and exploitation [...]. In her oeuvre, the balance of these elements varies from book to book" (28). Carnie Holdsworth's willingness to adapt across literary forms and to experiment with genre was clearly challenging. The form of This Slavery, for instance, is effusively polyphonic, littered with quotations (often offset) from songs, poetry, the Bible, socialist, music hall, and popular culture, as well as from canonical literary works. At the start of Book II, after mill-girl Hester Martin has attempted to "sail out of it [This Slavery] in the barque of Matrimony" (117), "Time-Imp Sings the Prologue" in two stanzas of twenty- 
two line verse, disrupting both the page and the progress of the plot. In broad sympathy with the formal experimentation characteristic to other socialist novels of the time, including Robert Tressell's earlier The Ragged Trousered Philanthropists (1914), the narrator of This Slavery seeks to challenge readers' assumptions about form and plot from a consciously political and socially realistic standpoint:

I am sorry if you had expected the curtain to ring down on a beginning which is traditionally the ending of a tale. I am sorry if sometimes you lose sight entirely of the hero and heroine - or rather the two heroines and heroes - or see them jammed at times, helpless units in the mass. Such is life. (122)

But re-reading Carnie Holdsworth as a serial or "newspaper novelist" also sheds light on the balance in some of her longer novel-length fictions. In "The Great Experiment," Cora Drummond is inspired to represent Fiddle-row and its varied characters as follows:

Great things had happened in Fiddle-row - to her memory. Sad things, sweet things, comical things had been enacted in those huddled houses. There was the woman who stole the six spoons of the Apostles, and went to gaol for six months though fancying them! And the tin-whistle player, and Mrs. Casey, who had buried all her children but one, and 
Dan Crowther, who had had his water-tap cut off because he would not pay water rates, and Sanders Winters, who drank himself to death after his wife died. (February 3 1923, 42)

The short, episodic nature of the serial story enabled the introduction of fleeting though sharply drawn characters like this, alongside more fully drawn protagonists to accompany the reader through the narrative. Well-practiced in the art of rapid characterization through her serial and short story work, Carnie Holdsworth's novels, as Belinda Webb has pointed out, "giv[e] regular 'walkon' space to many characters" ("Introduction” xxi) who then disappear from view. The high level of incidents, dramatic opening scenes, and immediately sympathetic protagonists in Carnie Holdsworth's plots help to distinguish her first and foremost as a serial novelist. As Joseph and Cumberland note in How to Write Serial Fiction:

These readers demand a swiftly-moving story, that starts with a 'kick,' and ends with a stronger 'kick,' the story must start straight away, dramatically, with the principal characters introduced deftly, and a strong, interesting, puzzling 'curtain' arrived at - a 'curtain' that so stimulates curiosity that the reader must go on with the tale $[\ldots]$ For the purposes of most serial plots, at least three principal characters must be introduced in the first instalment, and five, or an even greater number of characters, is more usual. It follows then, that the greatest 
economy of words, and the highest technical skill must be used to introduce, say, five characters, their environment and circumstance in the space of five or six thousand words. $(79,83)$

The opening installment of This Slavery, first published in The Daily Herald (October 1923), closely follows this advice. The story begins in medias res - "Mrs. Martin was out" - with concise scene setting and characterization of the central protagonists (sisters Hester and Rachel Martin, their mother and grandmother, romantic hero Jack Baines). Short passages of dialogue, as Joseph and Cumberland advised, are broken up by descriptions of the character's mannerisms and actions. The first chapter is full of dramatic and romantic incidents, with scenes of domestic poverty, hunger, Jack and Hester's declaration of love for each other followed by Mary's dramatic rebuttal, and street scenes with brawls and domestic violence. It concludes with the most devastating of neighborhood and personal dramas, fire at $t^{\prime}$ mill:

Was it Barstocks or Ben Bridge? That was the great question. With anxious hearts and faces they rushed on through the night. It meant semi-starvation if it was Barstocks. From every direction came the sound of those anxious thousands, shawled figures, men, and even children running to the scene of the fire (19). 
If Carnie Holdsworth was well studied in the craft and techniques of serial fiction, she was more cavalier in her approach to literary genre. Over the course of her career, Carnie Holdsworth tried her hand at several different genres, including the industrial novel, romance, detective fiction, slum fiction, the gothic, the New Woman novel and the crime novel. The extent of her eclecticism was ill advised on some fronts: in general, publishers and readers liked to know what to expect from their authors. As Margaret Irwin wrote to her publisher, Harold Raymond, in May 1930: "you know what a help it is to the library reader to be able to tack some definite quality, if not subject, on to a writer" (Reading. University of Reading, Special Collections. Chatto \& Windus archive, CW 35/11.). ${ }^{\text {vii }}$ Contemporary manuals, as Peter Keating points out, advised young authors to establish "a reputation in the magazines for a special kind of story:" "Mr Kipling is identified with Indian life, Mrs Stannard ('John Strange Winter') with cavalry life, Mr G. R. Sims with London life (of a sort), while Mr Anthony Hope, Mr Machen, and others are all specialists in fiction" (Keating 340-1). According to Keating, the stratification of print culture at the end of the nineteenth and beginning of the twentieth centuries "encouraged novelists either to specialise in one particular kind of fiction, or, if the writer was exceptionally talented (or facile) to move between different kinds, thus profiting from (or taking advantage of) several sectors of the fragmenting market" (340).

We cannot know why Carnie Holdsworth chose to experiment so radically across so many different literary genres. Partly, it may have been a 
sense of the relative freedom afforded by writing for serial publication first rather than book-form; partly, it may have reflected the generic eclecticism of her own tastes and reading patterns, education, and enjoyment of popular texts. Roger Smalley argues that Carnie Holdsworth was a propagandist who sought to promote socialist values and "use imaginative writing on behalf of the people" (50). It is likely that writing across different popular genres enabled her to reach a wide audience. There was a long cultural tradition, as Smalley and Deborah Mutch have pointed out, of socially committed writers incorporating popular forms into their fiction as both a democratic gesture and so as to educate and entertain.

Carnie Holdsworth continued this tradition on two fronts, both writing for and revising the structures of popular fiction. The plot of This Slavery is a classic example of this, with its combination of Marxist-feminist rhetoric and adaptation of the popular rags-to-riches romance. Hester and Rachel Martin are immediately recognizable as headstrong mill-girl heroines, but in contrast to typical romances written for working-class women readers like those in the twopenny weekly Peg's Paper (1919-40), Hester's rags-to-riches marriage involves her in another form of slavery: "I have reduced my Slavery from being a slave of many to being a slave of one" (138). Carnie Holdsworth also wrote "inside" such publishing structures. In 1929, she published a romantic novelette, "All On Her Own," in Ivy Stories, a four-penny paperback magazine of complete stories, published every fortnight. Though working within the familiar structure of the popular romance - the last sub-heading of the story, 
for instance, reads "Love at Last" - themes of failed marriage, land ownership, and the death of an impoverished child bring in a prominent feminist and socialist perspective. Significantly, the "fair" protagonist Estelle Gardiner (1), a foundling, does not discover herself to be of noble birth as would often happen in popular narratives. If we concede to linguists and genre theory that genres are "central to human meaning-making and to the social struggle over meanings" (Frow 10), we might also read Carnie Holdsworth's formal and generic experimentation as an aesthetic working-out of her political principles. The literary manipulation of genre, as critic John Frow explains, is indicative of a radical desire to re-make the world:

[W] hat we learn, in 'doing' genre (in performing and transforming it), is the values we share or don't share with others and the means with which to challenge or defend them. Through the use of genres we learn who we are, and encounter the limits of our world. (144)

Carnie Holdsworth is an important but much-neglected working-class writer of the Left. If we assume that it is not helpful to categorize her legacy in terms of either firsts (though she was probably one of the earliest published British working-class woman novelists) or apparent rarity, what is important to readers and literary history is the powerful body of writing that remains. More of this is to be discovered. While my own work and that of others has so far gravitated towards the rare surviving copies of Carnie Holdsworth's novels 
in book form, changes in critical practice and methodology, with an increased interest in periodical culture coinciding with the technological benefits of digitization, may facilitate a much wider study of Carnie Holdsworth's serializations and short stories. The majority of these are still largely concealed in the vast archives of the periodical press (where these have survived, and this is less often the case with provincial titles). Working-class periodicals and socialist newspapers have yet to benefit from the kind of critical and financial investment in digital initiatives, of course, that have recently transformed research and teaching in modernist studies of a similar historical period (Latham 411-2).

As a writer, Carnie Holdsworth has often faced censure and criticism: too radical for some and not radical enough for others, distracted supposedly by her eclectic use of genre from where the place of narrative and historical interest ought to be. Following the initial wave of recovery spearheaded in the 1970s and early 1980s by H. Gustav Klaus, Ruth and Eddie Frow, and Mary Ashcroft, Carnie Holdsworth has recently been reclaimed by feminist critics. She has still to be discovered by ecocritics who might find her sensuous and powerful writing about nature a purposeful bringing together of the "Red and the Green" (Rignall and Klaus 1). I conclude with these comments because the way we write about working-class writing - in collections like this as well as outside of them - continues to affect how we read and teach the texts of working-class writers and how often or not they are read. Writing critical assessments about writers within the modest forms of power at our disposal is 
a form of patronage or, what Pierre Bourdieu might have dubbed, the "power to consecrate" (42). Ethel Carnie Holdsworth would no doubt have scoffed at any latter-day academic patronage - she reported leaving a WEA summer school in Oxford early as she disliked the form of education on offer and felt like a "duck in pattens" ("The Authoress of Our New Serial Story" 999). But obscurity sits uncomfortably with such a powerful and prolific writer keen to address a mass reading audience through a variety of genres, forms, and means. Perhaps she would react with wry amusement at being included in this volume from Cambridge University Press.

\section{Acknowledgements}

With many thanks to Chris Lynch who shared his extensive knowledge of rare sources on Ethel Carnie Holdsworth as well as his ongoing research into her publication history. 


\section{Works Cited}

Anon. “'Miss Nobody' - and its Author.” The Wheatsheaf (Manchester).

November, 1913. 85-6.

Anon. "The Authoress of Our New Serial Story." The Co-operative News. July

21, 1915, 998-999.

Anon. "Ex-Mill Girl Who Became a Literary Celebrity." The Yorkshire

Observer. April 5, 1932, 11.

Bell, Lady. At the Works: A study of a manufacturing town. London: Virago, 1985.

Besant, Walter. The Pen and The Book. London: Thomas Burleigh, 1899.

Bourdieu, Pierre. The Field of Cultural Production: Essays on Art and

Literature (New York: Columbia UP, 1993).

Carnie Holdsworth, Ethel. [pub. Ethel Carnie] "Factory Intelligence." The

Woman Worker (London). March 10, 1909. 219.

----- [pub. Ethel Carnie] "The Factory and Content." The Woman Worker

(London). March 31, 1909. 312.

----- [pub. Ethel Carnie] "How Colour is Introduced.” The Woman Worker

(London). April 7, 1909. 323.

----- [pub. Ethel Carnie] “Living Pictures.” The Woman Worker (London).

November 3, 1909. 416.

----- [pub. Ethel Carnie] "Miss Nobody: A Working Girl's Love Story.” The

Christian Commonwealth. June 11 - September 24, 1913. 
----- [pub. Ethel Carnie] Miss Nobody. Ed. Nicola Wilson. Kilkerran: Kennedy \& Boyd, 2013.

----- [pub. Ethel Carnie] "The Iron Horses”. The Co-operative News. July 31 December 11, 1915.

----- [pub An-Ex-Mill-Girl] Helen of Four Gates. Ed. Nicola Wilson.

Kilkerran: Kennedy \& Boyd, 2016.

----- [pub. Ethel Holdsworth] “The Great Experiment.” The Queenslander

(Brisbane). December 30, 1922 - March 17, 1923.

----- [pub. Ethel Holdsworth] General Belinda. London: Herbert Jenkins, 1924.

----- This Slavery. Ed. Nicola Wilson. Nottingham: Trent Editions, 2011.

----- “This Slavery.” The Daily Herald. October 1923 - February 1924.

----- Letter. The Sunday Worker. July 26, 1925. 6.

----- [pub. Ethel Holdsworth] "The Beggar Prince.” The Age (Melbourne,

Victoria). November 28 - December 30, 1932. National Library of Australia.

http://trove.nla.gov.au/newspaper/result?sortby=dateAsc\&q=\%22ethel+holds worth $\% 22+$ beggar+prince $\& s=0$

Fox, Pamela. Introduction. Helen of Four Gates. Ed. Nicola Wilson.

Kilkerran: Kennedy \& Boyd, 2016. Ix-xxxiii.

Frow, John. Genre. London: Routledge, 2006.

Frow, Ruth and Eddie. "Ethel Carnie: writer, feminist and socialist." The Rise of Socialist Fiction 1880-1914. Ed. H. Gustav Klaus. Sussex: Harvester Press, 1987. 251-66. 
Hammond, Mary. Reading, Publishing and the Formation of Literary Taste in England, 1880-1914. Farnham: Ashgate, 2006.

H.O.B. “A Propaganda Novel.” The Plebs. October 1925, XVII. 408-9.

Joseph, Michael and Marten Cumberland. How to write serial fiction. London: Hutchinson, 1927.

Langhamer, Claire. Women's Leisure in England, 1920-60. Manchester:

Manchester University Press, 2000.

Latham, Sean. "New Age Scholarship: The Work of Criticism in the Age of the Digital." New Literary History 35.3 (2004): 411-26.

Law, Graham. Serializing Fiction in the Victorian Press. London: Palgrave, 2000.

Malcolm, David. “Bedazzled.” TLS (London). March 7, 2014. 28.

Mutch, Deborah. Ed. British Socialist Fiction, 1884-1914, vol. 1, 1884-1891.

London: Pickering \& Chatto, 2013.

Nash, Andrew. "The Production of the Novel, 1880-1940.” Eds. Patrick

Parrinder and Andrzej Gasiorek. Oxford: OUP, 2011. 3-19.

Rignall, John, and H. Gustav Klaus. Eds. Ecology and the Literature of the

British Left: The Red and the Green. Farnham: Ashgate, 2012.

Smalley, Roger. Breaking the Bonds of Capitalism: the political vision of a Lancashire mill girl. Lancaster: Lancaster University, 2014.

\section{Endnotes}




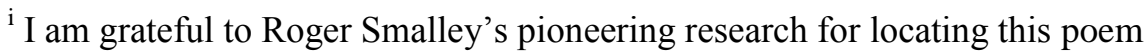
(Smalley, 59). British Library Jaffray Collection, 168/31.

${ }^{\text {ii }}$ For some of the debates about the reading of fiction in this period see the work of Mary Hammond.

${ }^{i i i}$ Most of Carnie Holdsworth's novels, published by Herbert Jenkins, sold at the average retail price for hardback fiction of either six shillings, or seven shillings and sixpence, before going into a two shilling 'Popular' edition. This Slavery, published by The Labour Publishing Company rather than Herbert Jenkins, was an exception in being published in a first edition at two shillings and sixpence.

iv In an interview for Woman's Outlook we learn that "The Marriage of Elizabeth" and "The House that Jill Built" are now appearing in book form "after running as serials in current periodicals" ("Ethel Carnie Holdsworth: A Notable Lancashire Woman Novelist", 295). Three stories about "General Belinda" first appeared in The Wheatsheaf (July 1920, 101-2; September 1921, 133-4; April 1922, 53-4) (Smalley, 114 n.3). Both Roger Smalley and Chris Lynch have carried out extensive bibliographical research on Carnie Holdsworth's serialization history.

${ }^{\mathrm{v}}$ Postcard from E. Holdsworth to W. Hardisty, September 10, 1924. Hebden Bridge Local History Society archive, MISC 8/4.

${ }^{\text {vi }}$ Ethel C. Holdsworth to the Authors' Syndicate. Rec. July 4, 1917. Wigan Records Office. I am grateful to Chris Lynch for alerting me to this letter. 
${ }^{\text {vii }}$ Reading. University of Reading, Special Collections. Chatto \& Windus archive, CW 35/11. 